\title{
On the Vascular Structure of some Species of Gleichenia.
}

\author{
L. A. BOODLE, F.L.S.,
}

\author{
AND \\ W. E. HILEY, B.A.,' \\ Queen's College, Oxford.
}

With Plate XXIX, and three Figures in the Text.

THE first full account of the anatomy of species of Gleichenia was given by Poirault in 1893 . All the forms known to him were protostelic, and in these he carefully described the curious nodes, and the manner of departure of the leaf-trace. More recent observations on the vascular structure in this genus have been published by Boodle ('01), Jeffrey ('02), and Tansley ('07). In the first of these three papers the most important feature was the description of the anatomy of $G$. pectinata (Willd.), $\operatorname{Pr}$., this species being specially interesting, as it differs from all the other members of the genus, as far as they are known, in having a solenostelic rhizome. The account of $G$. pectinata, given by Boodle ('01), was naturally incomplete, being founded on the examination of a small amount of dried material. Through the kindness of the late Mr. G. S. Jenman, who sent a supply of rhizomes preserved in spirit from British Guiana, we have been able to make a more extended study of the anatomy of this species. The results are given in the present paper, together with some observations on other species of Gleichenia, ${ }^{2}$ which were re-examined for purposes of comparison.

\section{G. PECTINATA.}

G. pectinata is indigenous in tropical America, and appears to be confined to that region. It has a long trailing rhizome, which is approximately cylindrical, and bears the leaves at intervals of from four to six inches on its

1 From the Jodrell Laboratory, Royal Botanic Gardens, Kew.

- G. fabellata, R. Br., G. circimata, Sw., with var. semivestita and G. dicarpa, R. Br. The material was obtained from living plents. grown at $\mathrm{Kew}$.

[Annals of Botany, Vol. XXIII. No. XCL. July, 1909.] 
upper side. The leaves are of the so-called dichotomous form, ${ }^{1}$ and have long pinnules; the last feature being one of the characters of the subgenus Mertensia, in which this species is placed.

\section{Internode.}

A transverse section of a fully developed internode is represented diagrammatically in Plate XXIX, Fig. 1. The cortex (c.) consists of brown sclerenchyma, and is bounded externally by an epidermis, and internally by a well-marked endodermis. A zone of cortex, two or three cells in thickness, and just external to the endodermis, is distinguished from the rest of the cortex by the greater thickening of the cell-walls. ${ }^{2}$ Three layers of thin-walled parenchymatous cells constitute the pericycle, within which there is a continuous ring of protophloem with metaphloem on its inner side. There is, as a rule, only one layer of parenchyma (mesocycle) between the phloem and xylem. The xylem, which has an annular form, is mesarch, and is composed of tracheae ${ }^{3}$ and parenchyma, intermingled in the same way as in other species of Gleichenia. ${ }^{4}$ The tissues within the ring of xylem form a series arranged in reversed order as compared with the similar tissues outside, and are as follows: inner mesocycle, metaphloem, protophloem, pericycle, endodermis, and lastly sclerenchyma. The scleren. chyma, which occupies the central space, is of the same nature as that forming the cortex, and its outer elements usually have smaller lumina than those nearer the centre, but there is nowell-marked zone of thick-walled cells like that of the inner portion of the cortex.

The rhizome is distinctly dorsiventral in structure, even where unaffected by the proximity of a leaf-trace, since the protoxylems of the lower half of a transverse section are differently situated (as regards immersion in the metaxylem) from those of the upper half. In the stem, a node of which is about to be described, there were seven of the lower kind of protoxylems and four of the upper, but these numbers are not constant, though their proportion is approximately maintained. The lower protoxylems (which are connected with the roots) are distinguished by having no large tracheae outside them; they are situated in xylem-promontories, in which they are covered by only a few small scalariform tracheae. On the other hand, the protoxylems of the upper part of the xylem appear deeply embedded, as the tracheae on the outside are large, like those on the inner

1 See Goebel ('05), vol. ii, p. 319 ; Tansley ('07), p. 135 ; Bower ('08), p. 553.

- There is sometimes one layer of thin-walled cells between the endodermis and this zone of specially thickened cells.

- These are to be classed as ressels. Some of the mature tracheae were carefully examined, and the pit-membrane was found to be missing. See Grynne-Vaughan (08).

4 The parenchymatons elements of the rylem may become lignified; one case was noted in which nearly all the xylem-parenchyma had undergone this chenge. 
side of them. The outline of the xylem is not disturbed by the upper protoxylem-groups, hence there are no promontories on the upper surface of the xylem-ring.

\section{Node, \&c.}

In the present instance the lowest cross-section affected by the node was at a distance of $2.9 \mathrm{~cm}$. behind the axil of the petiole, or $2.6 \mathrm{~cm}$. behind the point of complete separation of the leaf-trace from the stele. The first stage of preparation for nodal structure had been reached in the section shown in Plate XXIX, Fig. 3 ; here the protoxylem-elements at $y$ I have become slightly scattered, and the parenchyma in their neighbourhood has increased in bulk, forming the beginning of a nodal island. In sections cut serially towards the growing apex it was next noticed that, towards the inner side of this mass of parenchyma, a few elements of protophloem, and subsequently metaphloem, arose ; meantime the protoxylem branched, and formed two clusters, one at each end of the parenchymatous island. In the middle of the latter a few fibres were soon discernible; the lowest section containing them showed one fibre only, surrounded by an endodermis; but even this did not appear until the phloem had increased to about twenty elements, all of which were situated on the inner side of the group of sclerenchyma, and were separated from the endodermis by a single layer of parenchyma. By this time there was a radial band (Plate XXIX, Fig. 3, $r . b$.$) , composed of about three layers of xylem-parenchyma, connecting the$ parenchyma of the island with the inner mesocycle. This band of parenchyma next became broader, and the phloem spread into it from either end, until the phloem of the nodal island and the inner phloem of the solenostele were eventually united. At this stage a few elements of protophloem (Plate XXIX, Fig. 4, ab. ph.) were noticed in the nodal island on the abaxial side of the sclerenchyma. These elements were nowhere connected with the rest of the phloem, but they persisted for about $4 \mathrm{~mm}$. along the rhizome, and then disappeared. The effect of the failure of this phloem on the petiolar bundle will be discussed later.

Groups of fibres now arise near the protoxylems $y_{2}$ and $y_{3}$, and eventually near $y_{4}$; they increase in size, and, one by one, become joined to the original nodal mass of sclerenchyma belonging to $y \mathrm{I}$, the parenchyma becoming united first in each case. Protophloem-elements also arise independently near each of the lesser sclerenchyma-groups, and afterwards unite to form a continuous band of phloem in the composite nodal island, on the inner side of the sclerenchyma. As the radial band (Pl. XXIX, Fig. 5) broadens, the sclerenchyma at the centre of the stele, and that of the nodal island spread into it, so that the two masses become united by a narrow strip having phloem on each side of it. The cross-section of the sclerenchyma is now T-shaped (cf. Boodle, '01, Pl. XXXIX, Fig. 26). Each of 
the protoxylems $y_{3}$ and $y_{4}$ branches into two, thus giving $y^{\prime}, y_{3}{ }^{\prime \prime}, y 4^{\prime}$, and $y_{4}{ }^{\prime \prime}$ (cf. Plate XXIX, Fig. 6). The protoxylems $y 3^{\prime \prime}$ and $y 4^{\prime \prime}$ take no part in the formation of the foliar bundle.

The detachment of the leaf-trace from the stele of the rhizome takes place in the following manner. The radial band lengthens, and a gap is formed in the xylem between the protoxylems $y 3^{\prime}$ and $y 3^{\prime \prime}$, and through this gap the internal sclerenchyma, phloem, and endodermis become connected with the corresponding external tissues, the process being similar to the differentiation of the radial band, as described above. One end of the arched leaf-trace is thus separated (P1. XXIX, Fig. 6). Soon afterwards a similar interruption is formed on the other side between the protoxylemgroups $y^{\prime}{ }^{\prime}$ and $y^{\prime \prime}$, and the foliar bundle is then completely severed from the stele of the rhizome, leaving a leaf-gap, which, however, soon disappears. The protoxylems $y 3^{\prime \prime}$ and $y 4^{\prime \prime}$ by division give rise to the usual four upper protoxylems of the stele, and the normal internodal structure is restored. There is no distinct thickening of the 'margins of the leaf-gap', such as Gwynne-Vaughan ('03, p. 700 ), inferred from the earlier description of the node (Boodle, '01, p. 730).

The xylem of the leaf-trace is of the horseshoe type with incurved ends, and is endarch, several groups of protoxylem being scattered on the inner face of the arch. The phloem is continuous on the outer side of the xylem-arch, and on the inner surface of the incurved ends, but is absent in the inner middle region of the arch.

The description given above applies to nearly all the nodes examined, but in one node among the material sent by Mr. Jenman the structure was of a somewhat different type. In this case immediately the leaf-trace became detached from the stele of the rhizome one protoxylem-group of the leaf-trace ( $y_{3}{ }^{\prime}$ in Pl. XXIX, Fig. 6) became markedly mesarch, and a small group of fibres (accompanied by endodermis and phloem), branching off from the internal sclerenchyma, became immersed in the metaxylem in the neighbourhood of the protoxylem-group in question. In this way a group of tissue, resembling a small nodal island, came to be contained in the xylem of the leaf-trace near one of its extremities. Unfortunately the petiole had been cut off close to the base, so that it was not possible to trace the fate of the severed island. Another type of nodal structure was described by Boodle ('01, p. 730); in this case similar groups of tissue, resembling small nodal islands, became embedded in the xylem of the stele in the neighbourhood of the protoxylem-groups $y 3^{\prime \prime}$ and $y_{4}{ }^{\prime \prime}$, and this took place just before the separation of the leaf-trace. These secondary islands, which differ from the typical nodal islands in being extended acropetally, were apparently not continued for any great distance. 


\section{COMPARISON WITH OTHER SPECIES.}

In the species of Gleichenia examined two types of nodal island may be distinguished. In G. pectinata, G. flabellata, and G. linearis, Clarke, which belong to the subgenus Mertensia, the first stage in the formation of a nodal island is an increase in the number of cells of xylem-parenchyma near a protoxylem-group, as described above for $G$. pectinata. As this nodal island increases in size (i. e. when traced acropetally), it becomes associated with the neighbouring protoxylem-groups. Since the extended nodal island thus constituted forms the inner limit of the leaf-trace, the latter has endarch structure when it separates from the stele. The other type of nodal structure is shown by $G$. dicarpa, G. rupestris, R.Br., and $G$. circinnata, with its variety semivestita, belonging to the subgenus Eugleicherria. Here the nodal island does not originate in connexion with a protoxylem-group, and the xylem of the leaf-trace separateswith one or more of the protoxylems mesarch (cf. Boodle, '01, Plate XXXIX, Fig. 22).

A very young node of $G$. circinnata var. semivestita will now be described, and will furnish an example of the second type of nodal island. The node was at a distance of about $\mathrm{I} \mathrm{cm}$. from the growing apex. The structure of the stem showed signs of dorsiventrality at an early stage; near the growing point the three lower protoxylems became lignified before the two upper groups, and soon gave off root-traces. Text-fig. I i shows the structure of the stem below the node ; I, 2, and 3 , are the lower protoxylems; $4 a$ and $4 b$ (derived from the branching of 4 ) and 5 are the upper groups. $4 b$ again branches to form $4 b^{\prime}$ and $4 b^{\prime \prime}$, and at the same time a nodal mass of parenchyma is differentiated (Text-fig. I $2, n . i$.), and is easily distinguishable from the surrounding immature tissue, which is destined to form normal xylem. The nodal mass of parenchyma is not immediately associated with a protoxylem-group, but is equidistant from the protoxylems $4 b^{\prime}, 4 b^{\prime \prime}$, and 5. It increases in size (when followed acropetally), and soon contains some phloem-elements. A new protoxylem-group ( 6 in Textfig. I 3) then arises, and has no connexion with any of the other protoxylems. Text-fig. 21 shows the lowest section of this protoxylem, the end-wall of the single trachea being seen in surface-view. In the transverse section this trachea was separated by a long distance from any other lignified element. It was itself very feebly lignified, but showed distinct sub-scalariform markings. Text-figs. $2_{2}$ and $2_{3}$ are from higher sections, two protoxylem-elements being present in Fig. 23.

To return to the general description of this node, in the next stage after that shown in Text-fig. $I_{3}$, the xylem becomes cut across between the protoxylems 5 and 6 , and between $4 a$ and $4 b^{\prime}$, the endodermis insinuating

1 This species was referred to under the name of G. dichotoma in 'Anatomy of Gleicheniaceae' (Boodle, '01). 


\section{Boodle and Hiley.-On the Vascular Structure of}

itself between the stele and the leaf-trace (the process beginning on the left) in such a way that the nodal mass of parenchyma (i. e. undifferentiated sclerenchyma) never comes into connexion with the cortex. The leaf-trace
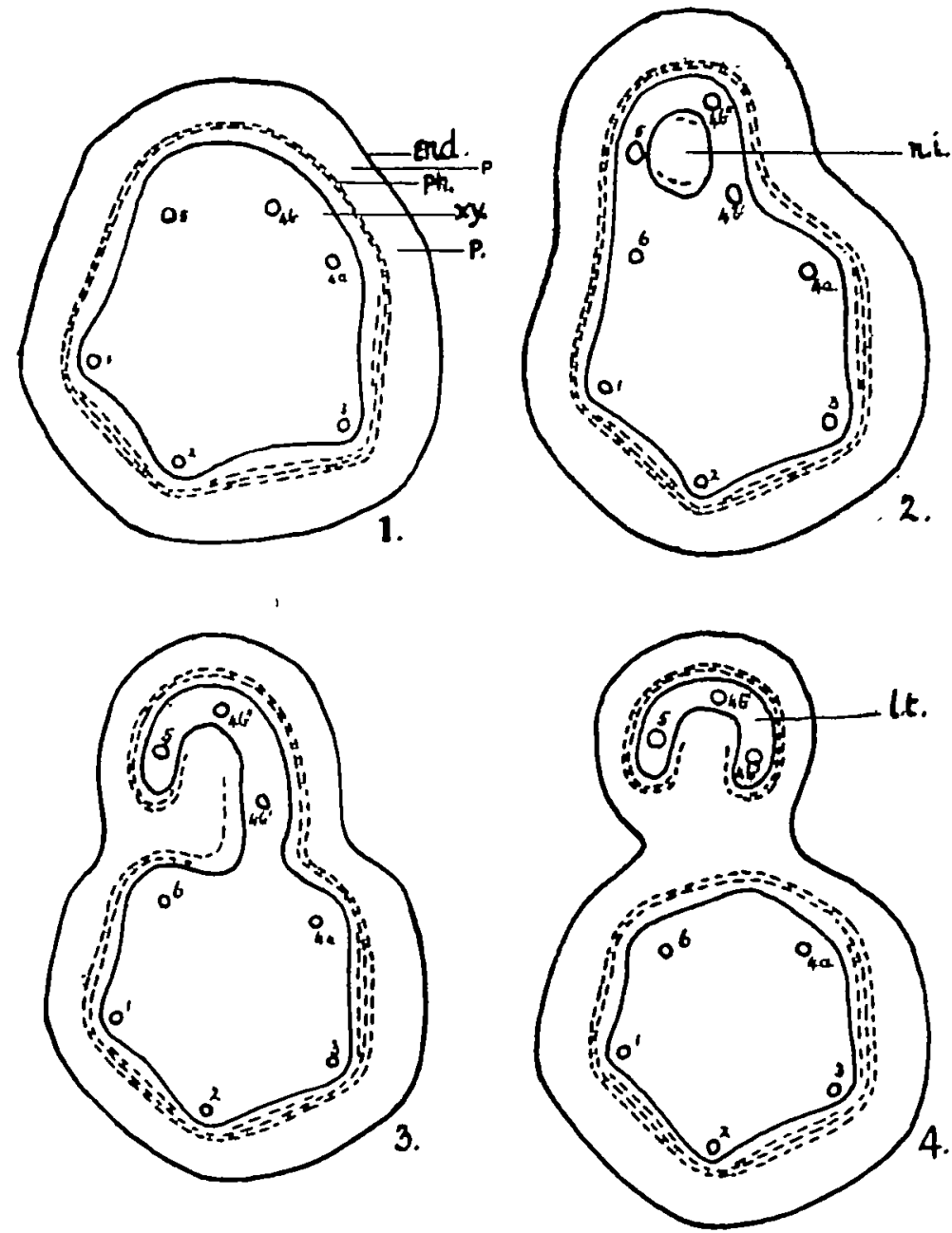

FIG. I Gleichenia circinnata. Transverse sections through a very young node. end. endodermis; n.i. nodal island; $p$. pericycle; $p h$. phloem. $1,2,3,4 a, 4 b, 4 b^{\prime}, 4^{b^{\prime}}, 5$, and 6 , protoxylems. $\times 50$.

takes with it the protoxylems $4 b^{\prime}, 4 b^{\prime \prime}$, and 5 , leaving $4 a$ and 6 to supply the upper protoxylems of the stele (Text-fig. I 4 ).

The mature node differs from the one just described in having a group of sclenrenchyma surrounded by an endodermis in the nodal island. In some of the cases examined this sclerenchyma became connected for a short distance with the cortex, but this is apparently not a constant feature. The 
number of fibres in the nodal island, or in its continuation in the petiole, varies considerably in different varieties; thus Boodle ('01, p. 725) found only three in G. circinnata, while for the var. Spelnncae, Poirault ('93, p. I81) figures a petiole with thirteen fibres, and in var. semivestita we found sixteen. In $G$. rupestris only a single fibre was present in one case.

The internal pericycle of the leaf-trace and petiolar bundle may become sclerenchymatous, ${ }^{1}$ this tissue being then composed of septate fibres with thick walls and numerous pits. ${ }^{2}$ Examples of this were found in G. circinnata, and may be compared with the case of G. alpina, R.Br. (=G. dicarpa
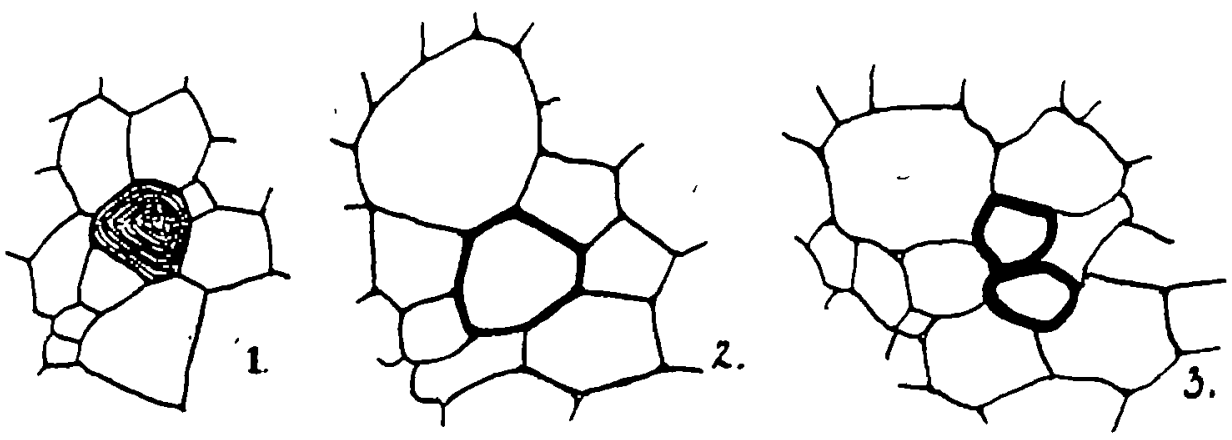

FIG. 2. Gloichenia circinuata. Protoxylem-element ( 6 in Fig. I). I. Lowest section of the element showing sub-scalariform markings. 2. Another section of the same, nearer the stem-apex. 3. Still higher section, showing two elements. $\times 540$.

var. alpina, H.B.), in which both inner and outer pericycle in the petiolar bundle become sclerotic (Boodle, '01, p. 716). The xylem-parenchyma in the stele may also become lignified and fibrous; but this was only observed in the variety semivestita, while specimens of typical $G$. circinnata did not show this character. Poirault, however ('93, p. I73), describes the presence of 'quelques rares cellules scléreuses' among the scalariform tracheae in G. alpina. R.Br. (G. hecistophylla, Cunn.). In G. circinnata and many other species of Gleichenia, including $G$. pectinata, phloem-fibres are occasionally to be found in the petiolar bundle.

\footnotetext{
I The pericycle of the nodal island may also become sclerenchymatons, e.g. in G. circinnata var. semivestita.

2 These septate fibres may be well shown by staining with Hofmann's blue, the preparations being made in the following way: Sections are soaked in ean de Javelle for abont five minutes, then washed in spirit, and treated with a solution of Hofmann's blue (Grübler's) in weak glycerine (50 per cent.). The tracheae and all other lignified elements stain deep blne. Permanent preparations may be made by mounting the sections in glycerine-jelly coloured with Hofmann's blue. The brown fibres of the cortex and nodal island remain brown (unless bleached by long soaking in eau de Javelle); they are thos easily distinguished from fibres belonging to the pericycle of the leaftrace or nodal island, since all these elements readily take up the blue stain. In the same preparations the dots on the radial walls of the endodermal cells were also well stained. Comparison with sections stained in phloroglacin showed that the action of Hofmann's blac, when used as described above, was limited to the walls which conld also be stained by phloroglucin. Mänle's reaction (with permanganate of potash, hydrochloric acid, ammonia) showed staining of the same walls, excluding perhaps the Caspary's dots.
} 


\section{Boodle and Hiley.-On the Vascular Structure of}

\section{Branching OF G. PECTINATA.}

In the rhizome of $G$. pectinata there are two kinds of branching, one monopodial, the other apparently dichotomous. The latter type appears not to be known to occur in the rhizome of any other species of the genus.
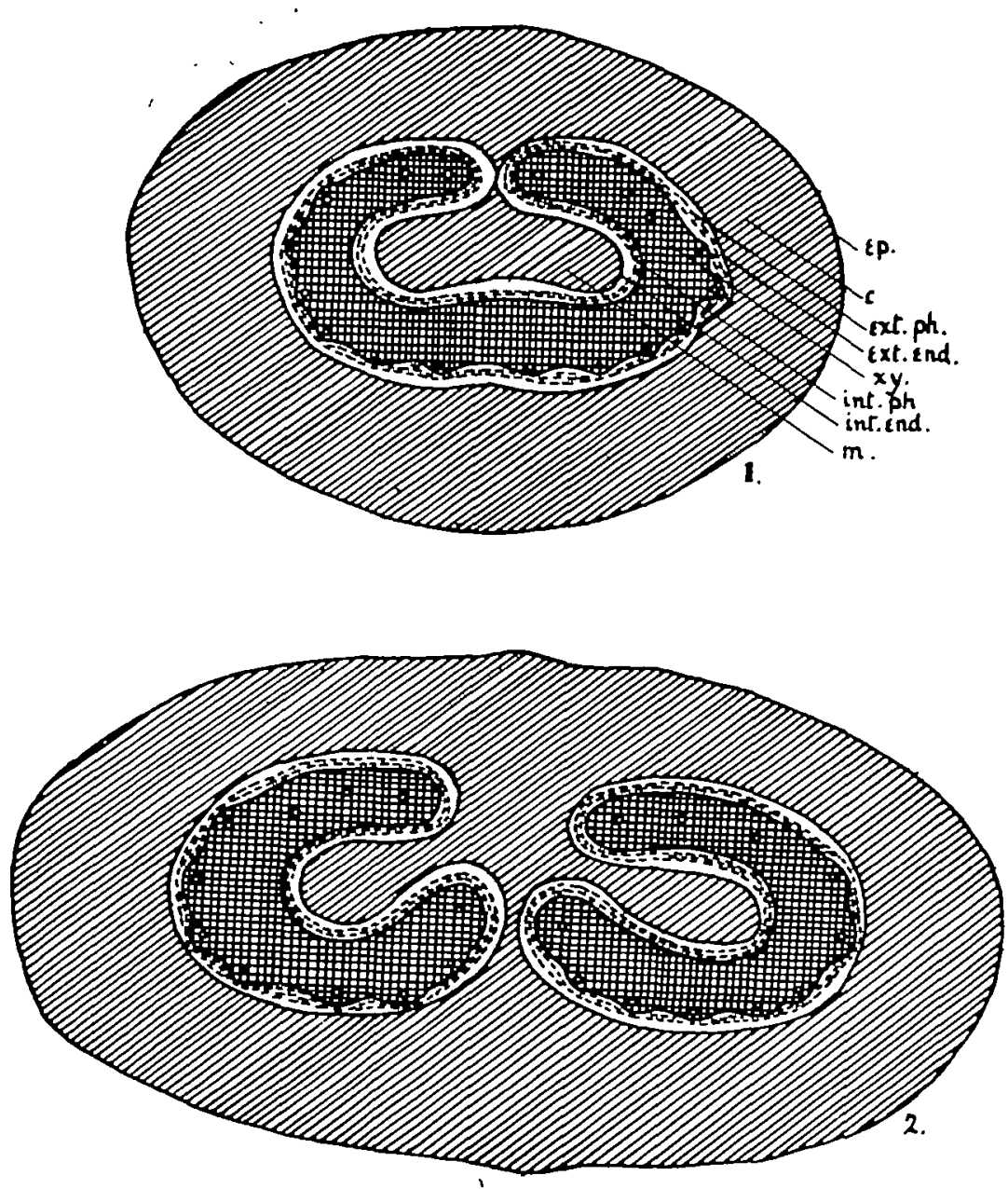

FIG. 3: Gleichenia pectinata. Transverse sections showing dichotomous branching. $c$, cortex; ep. epidermis; ext. end. external endodermis; ext. ph. extemal phloem; int. end. intemal endodermis ; int. ph. internal phloem; $m$. medulla; $x y$. xylem. $x$ abont $I 3$.

In $G$. pectinata monopodial branching always takes place in the vertical plane, the branch being uppermost, and all the protoxylems of the branch owe their origin to the upper protoxylems of the original stele (Plate XXIX, Fig. 8). Two protoxylem-groups of the upper kind are left in the lower 
stele, and these by division give rise to the full normal number. The two steles separate with open xylems, and in each of them the inner endodermis and phloem become continuous with the corresponding outer tissues. Thus a ramular gap is present (Plate XXIX, Fig. 9) but soon after their separation the two steles becomes closed again. The stele of the branch is smaller than that of the main rhizome. Plate XXIX, Fig. 9, shows that the separation of the two steles in monopodial branching bears a slight resemblance to the departure of a leaf-trace from the stele of the rhizome, but differs in the behaviour of the protoxylems and phloem; this may be seen by comparing Plate XXIX, Fig. 9 with Plate XXIX, Fig. 6 . There is also the difference that in monopodial branching no nodal island is formed ; the central mass of sclerenchyma simply enlarges so as to follow the changes in size and shape undergone by the stele before the separation of the branch.

Dichotomous branching is always in the horizontal plane, and the upper and lower protoxylems are equally concerned in supplying the two exactly similar branches. This necessitates an increase in number in both kinds of protoxylem. The stele becomes horizontally elongated, and divides first on the upper side, as shown in Text-fig. 3 I. In Text-fig. 32 the separation is complete, and the two steles are still open. Within a short distance they close again and resume the normal form. This is the usual mode of dichotomy, but in one case the two steles were closed when they separated, owing to the elongated stele having become constricted, and then nipped off in the vertical plane. Thus in the case of dichotomy a ramular gap may or may not be present.

One case was observed in which a dichotomy was closely associated with a node. A nodal island was formed in the xylem of a stele, which had become slightly elongated in the horizontal plane as a preliminary to dichotomy. The two processes of preparation for dichotomy and for separation of the leaf-trace then went on concurrently. The stele split on the upper side first, freeing one end of the leaf-trace; then the dichotomy of the stele was completed, the two steles being open, and the leaf-trace hanging on to the end of one of them, but very soon afterwards becoming free.

\section{Theoretical Considerations.}

Having described the nodal structure and the branching of the rhizome in $G$. pectinata, we may now consider the origin of the solenostelic structure of this species. It is to be expected that important data tending to the solution of this problem may be obtained from the anatomical study of some fossil Gleicheniaceae in the possession of Prof. C. Bommer, of Brussels, and possibly also from an examination of 'seedling ' plants of $G$. pectinata, when these can be procured.

In the absence of evidence of this kind, an attempt may be made to 
determine which is the most primitive type of stele among living species of Gleichenia, and provisionally to derive the other types from it. ${ }^{1}$

The genus Gleichenia, if Platyzoma be excluded from it, falls into two subgenera or sections, ${ }^{2}$ Eugleichenia and Mertensia. Of these, Eugleichenia, which includes $G$. circinnata, $G$. dicarpa, \&c., presents a series of apparently reduced forms, while most of the species of Mertensia, to which G. fabellata and $G$. pectinata belong, are not manifestly reduced.

The conclusion that reduction has taken place in Eugleichenia is based primarily on the comparative anatomy. In this subgenus the group of sclerenchymatous elements, which, as in most species of Gleichenia, is present in the nodal island, and is continued into the petiole, ${ }^{3}$ has but slight connexion with the similar elements of the cortex, and in G. circinnata (Boodle, '01, p. 726, Tansley, '07, p. ${ }_{3} 8$ ) it has no connexion whatever with the cortex. That this group of fibres was originally connected with the cortex of the petiole may be deduced from its resemblance to the cortical sclerenchyma, and from comparison with Mertensia, in which the sclerenchyma of the nodal island is continuous with the sclerenchymatous cortex filling the concavity of the arched petiolar bundle. The isolation of the group of fibres in G.circinnata is strong evidence that reduction has taken place, and the nearly circular or subcordiform petiolar bundle of Eugleichenia may be held to have been derived from the horseshoe-shaped bundle of the Mertensia-type by contraction, and by fusion of the free ends of the horseshoe, the sclerenchymatous cortex in the concavity of the latter thus becoming enclosed (see Boodle, '01, Fig. 23), or at a higher level suppressed. One species of Mertensia, viz. G. linearis, has undergone a similar reduction as regards its petiolar bundle, and is thus exceptional.

In two species of Mertensia, viz. G. pectinata and (one rhizome of) $G$. flabellata, a small amount of phloem was found on the abaxial side of the nodal island (Plate XXIX, Fig. 4, $a b$. ph.). As described above, this was a short strip, which had no connexion with any other phloem. Now from Plate XXIX, Figs. 2-7, it will be seen that, if this group of phloem-elements were slightly extended and continued up into the petiole, it would fill the gap in the phloem at present existing on the adaxial.side of the petiolar bundle. This suggests, firstly, that in the ancestral type of Gleichenia the phloem probably formed a continuous band round the xylem-arch in the

1 Cf. Boodle ('01), pp. 737, et seq., Tansley ('07), p. 142, \&c., Bower ('08), p. 562, where this subject is dealt with. A point of view suggested by the branching of the rhizome makes a re-statement of the theoretical position advisable.

' 'Subgenera' according to Diels (Engler and Prantl, Natürl. Pfantenfam.), who includes platyzoma as a third subgenus; 'sections' according to Hooker and Baker (Synopsis Filicum), who erclude Platysoma.

- In some species it is only continued for a short distance, i. e. into the basal part of the petiole, and in $G$. Boryi this group is entirely absent (Poirault, '98, p. 171). This would appear to be a case of extreme reduction. 
lower part of the petiole, and, secondly, that Eugleichenia, in which this remnant seems to have entirely disappeared, is less primitive than Mertensia, in which it still remains.

Turning now to the external morphology, we find that in Mertensia the pinnules are usually long ( $10-40 \mathrm{~mm}$.), while in Eugleichenia they are rounded and short (I-2 mm.). This is consistent with xerophytic reduction having taken place in Eugleichenia, and thus agrees well with the anatomical results.

For the reasons given above, Eugleichenia is to be regarded as consisting of a series of reduced forms, and as they appear to have been derived from forms of the Mertensia-type, the most primitive living species of Gleichenia should be sought for in the subgenus Mertensia, and G. flabellata may be taken as one of the most primitive species (Tansley, '07, p. 142). It has a simple protostele with a horseshoe-shaped petiolar bundle. ${ }^{1}$ It is interesting that, in soral characters also, this species appears to be primitive. On account of its possessing a pre-eminently large number of spores in the sporangium, and a radiate-uniseriate type of sorus in its most regular form, Bower ('08, p. 559) regards this species as probably the most primitive of those which he examined.

The existence, however, of solenostelic structure in G. pectinata raises a doubt as to whether the protostelic forms may not have been derived from solenostelic ancestors by reduction; the nodal islands of the simpler forms might then be regarded as remnants of the original central core of the solenostele. But a careful examination of the structure of $G$. pectinata shows that there is no sound basis for this view, for in this species the same type of nodal island is present, in addition to the central solenostelic complications (Tansley, '07, p. I42). Thus, until further evidence can be obtained, it seems justifiable to consider protostelic structure as primitive for the genus Gleichenia. ${ }^{2}$

We may now consider the origin of the solenostelic structure of $G$. pectinata, deriving it from the protostelic type of structure found in Mertensia. Three possible courses of evolution for the solenostele may be suggested :-

I. By decurrence ${ }^{3}$ from a leaf-trace, or

Ia. From a branch of the rhizome.

2. By decurrence ${ }^{4}$ from a branch of the rhizome, the protostele having previously become medullated.

3. Independently of decurrence, by a series of symmetrical changes in the rhizome.

I. Decurrence from the leaf-trace of $G$. pectinata gives rise to a nodal

1 For a description of the nodal structare see Boodle (' 01 ), p. 723 .

It is perhaps possible, but ander the circumstances not likely, that the protostelic forms might have been derived from the $G$. pectinata type by suppression of the tissues within the xylem-ring and retention of the nodal pocket.

This term is used metaphorically to imply basipetal extension by transformation of tissue in a phylogenetic series. See Boodle ('08).

4 Or procurrence; see below. 
island, which, at its base, is separate from the inner sclerenchyma, endodermis, and phloem of the solenostele, and also corresponds in position and structure to the nodal islands of other species of Gleichenia. This seems to show that in $G$. pectinata solenostely has not arisen by decurrence from the leaf-trace, but independently of the nodal islands.

Ia. Decurrence of phloem and cortical tissues from the axil of a branch or dichotomy of the stele is not known in any species of protostelic ferns (without pith), and there would not be any probability that decurrence should occur at the junction of two solid cylindrical steles, transverse elongation, lateral constriction, and nipping off being the natural mode of subdivision of a solid stele.

2. In some rhizomes of $G$. flabellata the tracheae were found to be less frequent in the central part of the xylem, the parenchymatous elements being complementarily more numerous. In this way, by the exclusion of tracheae from the central region, the protostele might become medullated. It would then be possible for ramular gaps to be formed by the departure of the branches. Through these gaps the cortical tissue, phloem, \&c., might become decurrent in the pith, thus forming an internal rod of these tissues (island in transverse sections), which would be central, if derived from a dichotomy. The decurrent tissues might be extended until they met the similar tissues at the next lower ramular gap, and a uniform stelar structure would be established, which, supposing leaf-gaps to be subsequently formed, would then become solenostelic. It may be objected that this theory requires an excessive and unlikely amount of decurrence, and for this reason it seems more probable that the converse of decurrence, i. e. an acropetal extension of tissues (which may be named 'procurrence '), may have been more largely concerned in the origin of the solenostely. At a ramular gap a slight upward as well as downward 'intrusion' of the tissues lying outside the xylem might occur (cf. the case of Osmunda cinnamonea, which may be an example of this kind; Faull, '01, Tansley, '07, p. 263, Kidston and Gwynne-Vaughan, '07, p. 775), and, when the meristem has begun to produce a certain type of structure, the acropetal extension of the latter would not perhaps be very surprising.

3. It may also be suggested that the solenostely has been developed by the rhizome, independently of the leaves and branches. The protostele having become medullated in the way described above, some elements of the medulla may have been differentiated as sieve-tubes forming a peripheral zone of phloem. Then it may be supposed that the inner medulla became sclerenchymatous, a change which necessitated the formation of an enveloping endodermal layer, when the formation of leaf-gaps would complete the solenostelic structure.

On general grounds the rarity (except in cases apparently to be explained by reduction) of a primarily disconnected tissue carries some weight against the likelihood of the last supposition (No. 3). 
The problem of the origin of solenostely in $G$. pectinata cannot be satisfactorily solved at present, but it appears probable that the derivation from protostelic structure may have been somewhat as follows :-

I. Mertensia-type of protostele with nodal islands.

2. Enlargement of stele in connexion with increase in size of arched leaf-trace.

3. Replacement of central part of xylem by a medulla.

4. Formation of ramular gaps.

5. 'Intrusion' of phloem, \&c., at ramular gaps.

6. Extension of these internal tissues throughout the length of the rhizome.

7. Formation of foliar gaps completing the solenostelic structure.

It is not easy to find any physiological advantage which the plant gains by its solenostely, apart from convenience of attachment for the phloem situated on the inner side of the hooks of the leaf-trace (see Pl. XXIX, Figs. $6,5)$. Working on the suggestion that the presence of internal phloem might mean an additional amount of this tissue, the area of the phloem and xylem was measured in camera lucida drawings of $G$. pectinata and $G$. flabellata; it was found, however, that though the area of the xylem in $G$. pectinata was double what it was in G. flabellata, yet the area of the phloem in the two cases was approximately the same. Thus, as regards proportional amounts, a distinctly negative result was obtained, but possibly the possession of internal phloem may have carried some advantage at an earlier stage in evolution, e. g. when ramular gaps but no leaf-gaps were present, if such a state of things existed.

\section{SUMMARY.}

Gleichenia pectinata shows regular solenostelic characters. The upper and lower protoxylem-groups differ in their degree of immersion in the xylem.

The structure of the node is similar to that of $G$. flabellata, but with the further complications due to the presence of leaf-gaps and solenostely. A nodal pocket is present; it is free in its lower portion, where it shows the typical structure of a nodal island, and in its upper course its different tissues become confluent with the corresponding internal tissues of the solenostele in relation to the formation of the foliar gap.

One curious feature at the node is the occurrence of a short disconnected strip of phloem-elements on the abaxial side of the nodal island; this may be considered as the remnant of a once continuous band of phloem, which formerly filled the gap at present existing in the phloem on the adaxial side of the xylem in the petiolar bundle.

In a node of G.circinnata var. semivestita a protoxylem-group was found to have a blind ending basally.

The rhizome of $G$. pectinata branches in two ways, monopodially in the 
vertical plane, and dichotomously in the horizontal plane. There is nothing resembling a nodal island in connexion with the branching. A ramular gap is generally present in both types of branching, but in one case of dichotomy the two steles were closed when they separated.

It is considered that Eugleichenia represents a series of forms showing reduction from the typical Mertensia-type, represented, e. g. by G. flabellata, and that Mertensia includes the most primitive species of Gleichenia, as well as the most advanced, viz. $G$. pectinata. The solenostelic structure of $G$. pectinata is to be regarded as derived from a protostelic Mertensia-type like that of $G$. flabellata. Among the possible modes of derivation of the solenostelic structure of $G$. pectinata from the type referred to, there is some probability that the course of evolution may have consisted in the formation of a pith and ramular gaps, followed by 'intrusion' of phloem, \&c., through a ramular gap into the pith, and subsequent extension of the structure thus attained throughout the rhizome.

\section{LIST OF WORKS REFERRED TO.}

Boodle ('01): On the Anatomy of the Gleicheniaceae. Ann. Bot., xv, p. 703.

Boodle ('08): On Degcriptions of Vascular Structures. New Phytologist, ii, p. I07.

Bower (08): The Origin of a Land Flora.

Faull ('01): Anatomy of the Osmundaceae. Botan. Gazette, xxrii, p. 381.

Gozbel ('05): Organography of Plants, Eng. ed.

Gwynne-Vaughan ('03): Observations on the Anatomy of Solenostelic Ferns. Part II. Ann. Bot., rvii, p. 689.

Gwynne-Vaughan ('08): On the Real Nature of the Tracheae in the Ferns. Ann. Bot., xxii, p. 517. JefrReY ('02): Stracture and Development of the stem in Pteridophyta and Gymnosperms. Phil. Trans. Roy. Soc., B., cxcv, p. IIg.

Kidston and Gwynne-Vaughan ('07) : On the Fossil Osmundacene. Part I. Trans. Roy. Soc., Edinburgh, xlv, p. 759.

Poirault ('93): Recherches sur les Cryptogames Vasculaires. Ann. Sci. Nat., Bot., $7^{\circ}$ sér., t. I8, p. II 3 .

Tansley ('07): Lectures on the Evolution of the Filicinean Vascular System. New Phytologist, vi, p. 135 .

\section{EXPLANATION OF FIGURES IN PLATE XXIX.}

Illostrating Messrs. Boodle and Hiley's Paper on the structure of Glicheria.

Lettering used in the illustrations : ab. ph. abaxial phloem; $c$. cortex; ep. epidermis; ext. erad. external endodermis; ext. ph. external phloem; int. end. internal endodermis; int. ph. internal phloem ; th. medalla ; $\pi . i$. nodal island ; ph. phloem; r.b. radial band; rf. root-trace; sc. sclerenchyma; $x y$. xylem. Protoxylem-groups are marked $y 1, y 2,8 x c, y 3^{\prime}, y 3^{\prime \prime}$, \&cc.

All the figures are of Gleichenia pectinata.

Fig. 1. Transverse section through internode. $\times 15$.

Fig. 2. Radial section through a node. $\times 7 \frac{1}{2}$.

Figs. 3-7. A series of transverse sections through the nodal region of the rhizome, arranged opposite their correct positions in the longitudinal section (Fig. 2). $\times 15$. $x$ II.

Figs. 8 and 9. Transverse sections through a thizome undergoing monopodial branching. 
Downloaded from https://academic.oup.com/aob/article-abstract/os-23/3/419/190150

by University of California, Santa Barbara user

on 11 March 2018 
Annals of Botany,
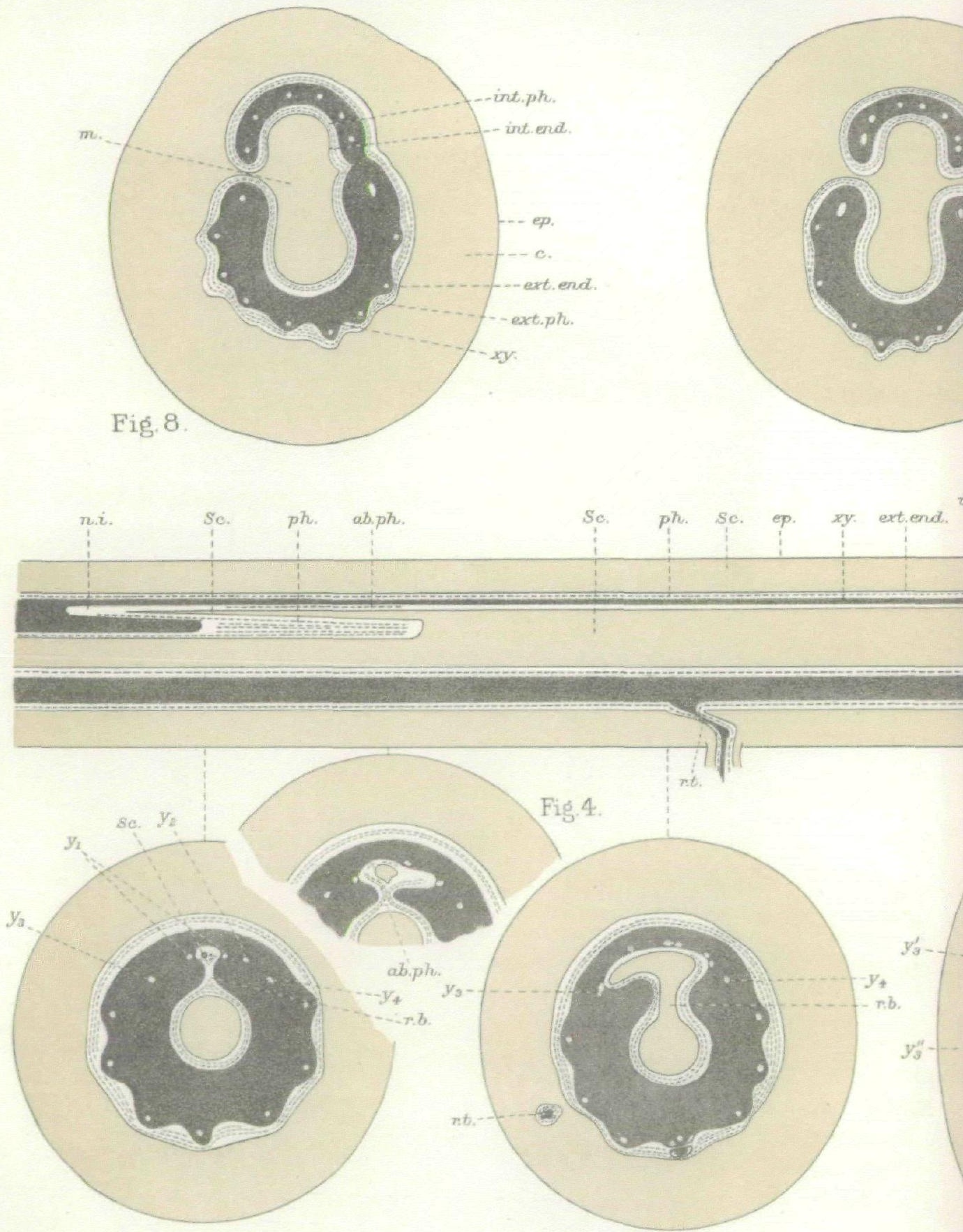

Fig. 3.

Fiǵ. 5.

W.E.H del.

BOODLE AND HILEY - GLEICHENIA. 
Fig.9.

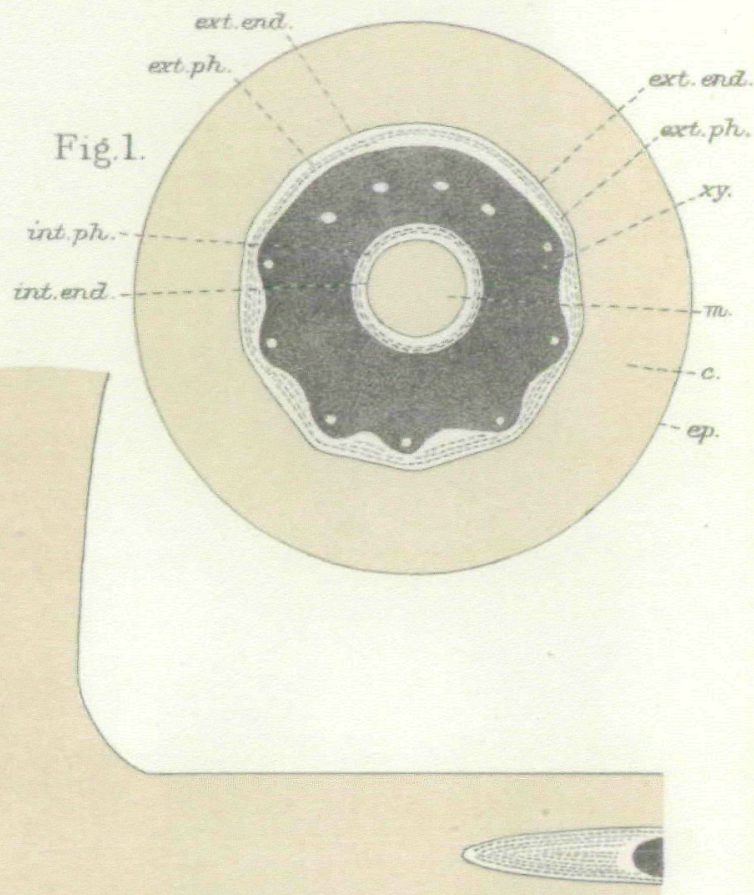

Fiǵ. 2.

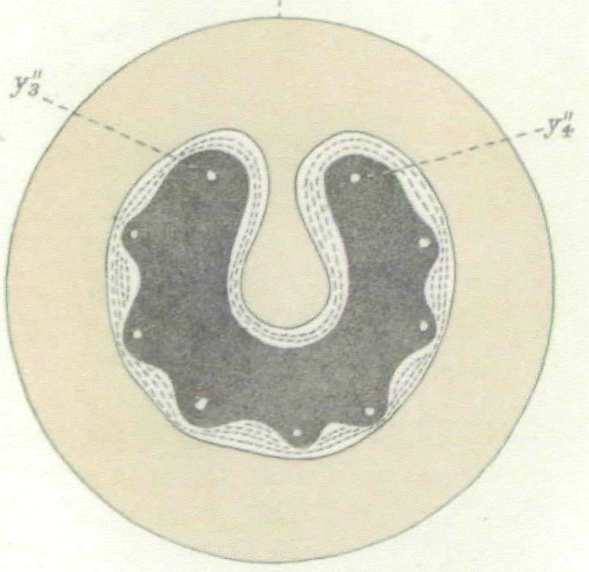

Fiǵ. 7.

Huth lith et imp. 
Downloaded from https://academic.oup.com/aob/article-abstract/os-23/3/419/190150 by University of California, Santa Barbara user

on 11 March 2018 